\title{
微量のエチレンを低温で除去する触媒 果物，野菜，花の鮮度を保つ技術
}

われわれの身の回りにある果物や野菜などさまざまな 植物からエチレンが放出される。このようにして放出さ れるエチレンの量は微量ではあるが, 果物, 野菜, 花の 腐敗を進める作用をもつために効率的な除去方法の開発 が求められてきた，特に，冷蔵下で果物，野菜，花の鮮 度を保って保管や輸送を行う社会的な要請は大きいた め，0ㄷ などの低温下においてもエチレンを除去できる 技術の開発は重要である.

これまでにエチレンを除去する方法として複数の方法 が考案され，実際に利用されてきた。その一つが，活性 炭やゼオライトなどの多孔質材料にエチレンを吸着させ て除去する手法である. 別の手法として, 酸化力の強い 金属成分によるエチレン分解除去剤の利用も拡大した. しかしながら，これらの吸着剂および分解除去剂はいず れも，再利用することができず，効力を失った場合には 交換をしなければならない。 また，オゾンガスを発生さ せることによって空気中のエチレンを分解する製品も実 用化されているが，大型の設備になってしまう。

そこでわれわれは，交換の必要がなく繰り返し利用可 能で効率の高い触媒を開発しょうと思った。「触媒」と は，自身は変化せずに化学反応を加速する物質のこと で，化学反応を大幅に効率化させる. 紫外線や可視光を 照射することで機能する「光触媒」を用いる手法 ${ }^{(1)} も$ あるが，われわれは光を照射する必要のない触媒の研究 開発に着手した。われわれは以前に, 燃料電池に用いら れる水素の中の微量の一酸化炭素を効率良く酸化除去す る触媒を開発した ${ }^{(2)}$. その知見と経験を活用して，さま ざまな種類の金属を数ナノメートル（ナノメートルは $10^{-9}$ メートル）の小さな微粒子状にして種々の材質の 上に固定化することで触媒を作製した。低濃度のエチレ ンガスを空気と同濃度の酸素と混合した後, 触媒の中を 通してエチレンが除去される効率を評価した。

種々の触媒で試した結果, 数ナノメートルの細孔を有 するメソポーラスシリカの細孔の中に固定化した白金の 微粒子が非常に高い効率でエチレンを除去する触媒とし て機能することを見いだした ${ }^{(3)}$ (図 1)。ここで用いたメ ソポーラスシリカとは, 2 〜 50 ナノメートルの規則的な 形の穴をもつシリカ $\left(\mathrm{SiO}_{2}\right.$, 二酸化ケイ素）であり, 吸
着材や触媒としての用途開発が進められている.

この触媒を用いると, $0{ }^{\circ} \mathrm{C}$ の低温下で $50 \mathrm{ppm}$ （0.005\%）という低濃度のエチレンでも完全に除去する ことが可能である.この際, エチレンは二酸化炭素と水 に酸化される，微量のエチレンを低温で除去するこの触 媒の性能はこれまでに論文で報告されていたいずれの触 媒 ${ }^{(4)}$ の性能も超えており, 実用化も可能ではないかと 期待している.

この触媒を長時間使用すると, 触媒の効力が少しずつ 減少してきた．エチレンの酸化によって生成する水が触 媒の表面に吸着することが性能低下の原因ではないかと 考えた。 そこで, 単純に触媒を加熱してみると元の効力 が回復され，エチレンの除去に繰り返し利用できること が確認された。

系統的なスクリーニングによってわれわれが見いだし た白金とメソポーラスシリカの組み合わせは非常に重要 であることがわかった、メソポーラスシリカを用いても 金属がパラジウム，金，銀などほかのものになると著し く触媒の性能が劣る。一方で，同様の大きさの白金の微 粒子が存在していても, 固定化に用いる材料がチタニ ア，アルミナ，ジルコニアなどシリカ以外の酸化物であ るとこちらも高い活性を得ることができない.

高い性能の触媒を発見できたことで十分という考え方 もあるかもしれないが，われわれは，白金とメソポーラ スシリカの組み合わせがなぜ必須なのかを解明したい. これまでに複数の測定手段を適用して触媒の詳細な構造

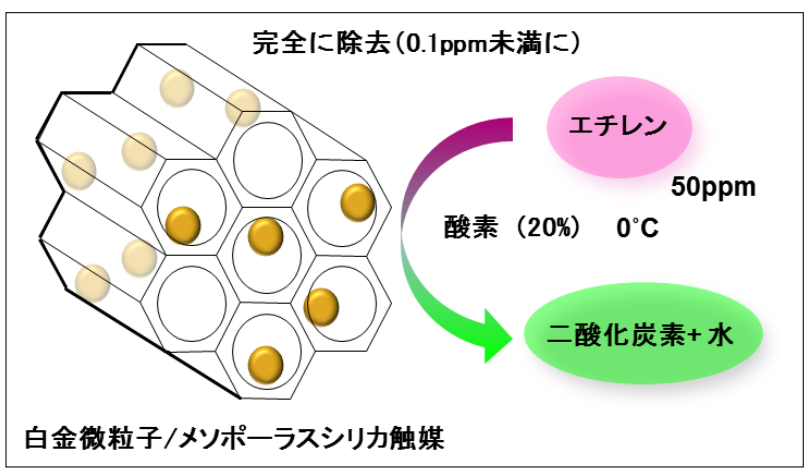

図 1 -メソポーラスシリカに担持した白金ナノ粒子によるエチ レンの低温除去 


\section{今日の話題}

や性質を調べてきた．電子顕微鏡を用いて金属ナノ粒子 の形状の確認を行ったほか，X線を照射して得られる回 折パターンから金属の結晶性やサイズに関する情報を得 た．また，反応中の触媒に赤外線レーザーを導入するこ とによって得られる吸収スペクトルを介して, 触媒の表 面に存在する化学種を観察する試みも行った。この赤外 分光を用いる手法からは, 触媒反応のメカニズムに関す る重要な情報が得られた。 エチレンの分解過程において 一酸化炭素が反応中間体になっていることが示されたの である。つまり，本触媒系では，エチレンがまず一酸化 炭素にまで分解し，生成した一酸化炭素が酸化されるこ とで最終生成物の二酸化炭素になるというメカニズムで エチレンの除去反応が進行していることが明らかになっ た．さらに赤外分光を用いた観察を詳細に行ったとこ 万，反応中間体の一酸化炭素が消失する速度は，白金と メソポーラスシリカの組み合わせである活性の高い触媒 表面において高いことがわかった，現在，さらに検討を 行っており，なぜこのような反応が起こるのかを解明し たい.

われわれの身の回りには，エチレン以外にもさまざま な悪影響をもたらす揮発性有機化合物（VOC）が存在す る. VOC とは，蒸発して大気中で気体状となる有機化 合物の総称である．住宅資材から放出されるホルムアル デヒドやトルエンはシックハウス（室内大気污染）の原 因となる化合物であり，これらを除去する技術の開発が 望まれている，VOCの除去に対しても，今回開発した 触媒に関する知見を応用できると期待している。 また, 貴金属以外の安価な金属を用いた触媒の開発も今後展開 すべき方向であると考えている.

家庭やオフィス，また，運輸や貯蔵の場において，わ れわれの開発した触媒が実際に利用されることを夢見つ つ, より高性能で実用性のある触媒の開発に今後も日々 取り組んでいきたい.
1) D. R. Park, J. L. Zhang, K. Ikeue, H. Yamashita \& M. Anpo:J. Catal., 185, 114 (1999).

2) A. Fukuoka, J. Kimura, T. Oshio, Y. Sakamoto \& M. Ichikawa:J. Am. Chem. Soc., 129, 10120 (2007).

3) C. Jiang, K. Hara \& A. Fukuoka: Angew. Chem. Int. Ed., 52, 6265 (2013).

4) C. Y. Ma, Z. Mu, J. J. Li, Y. G. Jin, J. Cheng, G. Q. Lu, Z. P. Hao \& S. Z. Qiao:J. Am. Chem. Soc., 132, 2608 (2010).

（原 賢二，福岡 淳，北海道大学）

プロフィル

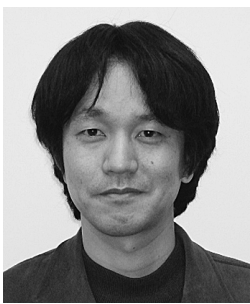

原賢二(Kenji HARA)

$<$ 略歴 $>2001$ 年東京大学大学院理学系研 究科化学専攻博士後期課程中退（就職の ため) /同年北海道大学理学部化学科助手 (後に助教) $/ 2007$ 年同大学触媒化学研究 センター准教授 (現職) <研究テーマと抱 負 $>$ 分子性の触媒の概念と固体や表面を扱 う触媒の概念を融合した触媒づくりに挑戦 しています。そのような挑戦のなかから社 会に貢献するブレークスルーにつながる成 果が出てくればと願っています＜趣味＞山 登りなどのアウトドア, 温泉, 旅行, 週末 の料理

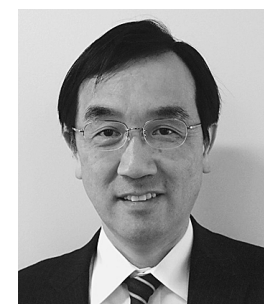

福 岡 淳 (Atsushi FUKUOKA) $<$ 略歴> 1982 年東京大学工学部合成化学 科卒業/1986 年北海道大学触媒研究所助 手 / 1991 年東京農工大学工学部講師（の ち助教授) / 1997 年北海道大学触媒化学研 究センター助教授 / 2007 年同教授 / 2010 年同センター長 < 研究テーマと抱負 $>$ 役に 立つ触媒づくりを目標に, 固体触媒による バイオマス変換とメソポーラス物質の触媒 作用の 2 つテーマとして研究を行ってい ますく趣味 $>$ 読書, 適度な運動 